\title{
(6) OPEN ACCESS \\ Socioeconomic variation in the incidence of childhood coeliac disease in the UK
}

\author{
Fabiana Zingone, ${ }^{1,2}$ Joe West, ${ }_{1}^{1}$ Colin J Crooks, ${ }^{1}$ Kate M Fleming, ${ }^{1}$ Timothy R Card, ${ }^{1}$ \\ Carolina Ciacci, ${ }^{2}$ Laila J Tata ${ }^{1}$
}

- Additional material is published online only. To view please visit the journal online (http://dx.doi.org/10.1136/ archdischild-2014-307105).

${ }^{1}$ Division of Epidemiology and Public Health, City Hospital Campus, University of Nottingham, Nottingham, UK ${ }^{2}$ Department of Medicine and Surgery, University of Salerno, Salerno, Italy

\section{Correspondence to} Dr Fabiana Zingone, Division of Epidemiology and Public Health, City Hospital Campus, The University of Nottingham, Clinical Sciences Building Phase 2, Hucknall Road, Nottingham NG5 1PB, UK; Fabiana.Zingone@nottingham. ac.uk

Received 3 July 2014 Revised 17 November 2014 Accepted 21 November 2014 Published Online First 22 January 2015

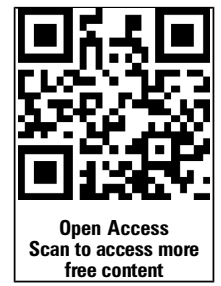

CrossMark

To cite: Zingone F, West J, Crooks CJ, et al. Arch Dis Child 2015;100:466-473.

\section{ABSTRACT}

Background Serological studies indicate that evidence of coeliac disease (CD) exists in about 1\% of all children, but we lack estimates of current diagnostic patterns among children and how they vary by socioeconomic group.

Methods We identified all children aged $0-18$ years between 1993 and 2012 who were registered with general practices across the UK that contribute to a large population-based general practice database. The incidence of $C D$ was evaluated in each quintile of the Townsend index of deprivation and stratified by age, sex, country and calendar year.

Results Among 2063421 children, we identified 1247 CD diagnoses, corresponding to an overall CD incidence of 11.9 per 100000 person-years, which was similar across the UK countries and higher in girls than in boys. We found a gradient of CD diagnosis across socioeconomic groups, with the rate of diagnosis being $80 \%$ higher in children from the least-deprived areas than in those from the most-deprived areas (incident rate ratio $1.80,95 \% \mathrm{Cl} 1.45$ to 2.22 ). This pattern held for both boys and girls and across all ages. Across all four countries of the UK, we found similar associations between $C D$ and socioeconomic status. While CD incidence up to age 2 remained stable over the study period, diagnoses at older ages have almost tripled over the past 20 years.

Conclusions Children living in less socioeconomically deprived areas in the UK are more likely to be diagnosed with CD. Increased implementation of diagnostic guidelines could result in better case identification in more-deprived areas.

\section{INTRODUCTION}

Screening studies among children in the USA and Western Europe report a seroprevalence of coeliac disease (CD) of around $1 \%{ }^{1-6}$ However, over the last two decades, several studies have reported an increased incidence of biopsy-detected CD in children, ${ }^{7}$ the reason for which is unclear. One explanation for the increase is that it represents improved ascertainment due to heightened clinical awareness underpinned by improved accuracy and availability of diagnostic tests ${ }^{8}$ and/or to screening programmes in people with associated diseases. ${ }^{9}$ If this increase in clinically diagnosed paediatric CD does only represent improved ascertainment, then one might expect it to be more marked in higher socioeconomic groups. This is because children of higher socioeconomic status are more likely to seek healthcare, ${ }^{10}$ and therefore opportunities for investigation in so-called 'at-risk' groups would be

\section{What is already known on this topic?}

Serological studies indicate that evidence of coeliac disease exists in about $1 \%$ of all children yet clinical diagnoses are much less prevalent.

- Existing studies on the socio-demographic distribution of childhood clinically diagnosed coeliac disease are in small study populations and findings are contradictory.

\section{What this study adds?}

- Clinical diagnoses of coeliac disease among children aged over 2 years have almost tripled over the last two decades.

- Children from the most socioeconomically deprived areas are only half as likely to be diagnosed with coeliac disease as those from less-deprived areas.

expected to occur more frequently among them, which may lead to more frequent testing for CD. ${ }^{11}$ The few studies that have investigated a possible socioeconomic gradient in CD have reported conflicting results. ${ }^{12-21}$ In view of this and the lack of population-based studies, assessing patterns of clinical diagnosis of $\mathrm{CD}$ among children in the UK, we examined the incidence of $\mathrm{CD}$ up to 18 years of age and its variation by socioeconomic group, taking into account age, sex, calendar period and country within the UK.

\section{METHODS}

Data were obtained from The Health Improvement Network (THIN), a nationally representative UK database of primary care records, containing medical diagnoses, events and drug prescriptions. ${ }^{22}$ Our cohort was all children aged $0-18$ years registered with a THIN general practice (GP) at any time from 1 January 1993 to 31 December 2012. We identified all incident diagnoses of $\mathrm{CD}$ based on the presence of one or more of the following Read codes recorded in children's GP records: J690.00Coeliac disease, J690.13-Gluten enteropathy, J690z00-Coeliac disease NOS. For patients with more than one CD code, the earliest was considered as the date of disease diagnosis. Children with $\mathrm{CD}$ 
recorded before their entry date were considered to have prevalent disease and were thus excluded.

The incidence of CD per 100000 person-years was calculated by dividing the number of children with $\mathrm{CD}$ by the total follow-up time contributed to the study period by all children. Incidence was stratified by age, sex, country of residence (England, Scotland, Wales and Northern Ireland), calendar year (grouped as quinquennia) and household socioeconomic quintile, measured by the Townsend index. ${ }^{23}$ Townsend index measures area-level (approximately 50 households) deprivation based on local unemployment, car ownership, overcrowding and home ownership from the 2001 Census; use of quintiles maintains anonymity.

Poisson regression was used to calculate unadjusted incidence rate ratios (IRRs) for CD by all factors, and potential interactions were assessed using the likelihood ratio test (LRT). Age was grouped into three age bands $(0-2,3-9,10-18)$, similar to that in previous demographic studies of CD. ${ }^{17} 2425$ Although prevalent $C D$ cases had been excluded, children with a first diagnosis recorded soon after their GP registration may have had prevalent disease upon study entry (diagnosed before but recorded near the time of GP registration). Therefore, we conducted a sensitivity analysis excluding patients whose first CD diagnosis or gluten-free product prescription was recorded within 6 months of initial registration unless they were diagnosed at younger than age 2 years. This method of excluding potentially prevalent cases was based on Lewis et al's ${ }^{26}$ but tailored to children since diagnoses very early in life are likely to be incident regardless of proximity to registration. We conducted a second sensitivity analysis to exclude potential CD overestimation using a restricted CD definition where cases had to have at least one gluten-free product prescription associated with their CD diagnosis. In the UK, children with CD are eligible to receive free prescriptions from their GP to purchase gluten-free foods, funded by the public National Health Service. While patients with $\mathrm{CD}$ are not required to obtain these prescriptions, they would not be received unless a definitive CD diagnosis was made. Analyses were performed using Stata V.12.

\section{RESULTS}

There were 2063421 children in our study population, contributing a total of 10508374 person-years. Their median follow-up was 3.8 years (IQR 1.5-7.9) and 1247 children were diagnosed with $\mathrm{CD}$, corresponding to an overall incidence rate of 11.9 per 100000 person-years.

\section{Socio-demographic distribution of CD diagnoses}

Table 1 shows variations in the rate of CD diagnosis by sex, age, country, calendar period and socioeconomic deprivation. The rate of CD in girls was 53\% higher (IRR 1.53, 95\% CI 1.37 to 1.72 ) than in boys. Incidence varied by age with the lowest $C D$ in children younger than 1 after which it increased to 18.7 and 17.9 per 100000 person-years at ages 1 and 2 years, respectively. Incidence then decreased, ranging between 8.4 and 15.1 per 100000 person-years between ages 3 and 18 years. We did not find significant geographic variation across the UK, with a similar CD incidence observed in the four countries. Across the 20-year period studied, there was a clear increase with a CD diagnosis rate in the last five years (2008-2012) that was $75 \%$ higher than in 1993-1997 (IRR 1.75, 95\% CI 1.31 to 2.34).

Table 2 shows how the incidence of CD varied by sex, age and country over the study period. There was a $39 \%$ increase in boys (IRR $1.39,95 \%$ CI 0.92 to 2.10 ) and a twofold increase in girls (IRR 2.09, 95\% CI 1.39 to 3.13). However, there was no statistically significant interaction between sex and calendar period (LRT $\mathrm{p}$ value for interaction $=0.4$ ). Conversely, across the three age groups studied, there was a statistically significant interaction with calendar period (LRT $\mathrm{p}<0.001$ ). Children aged $0-2$ years had a roughly constant CD incidence over time, whereas children aged 3-18 years had threefold increase from 1993-1997 to 2008-2012 periods. CD incidence increased over time in England and Scotland, while we did not observe a statistically significantly increase in Wales and Northern Ireland.

\section{Incident CD diagnoses across socioeconomic status}

We found a gradient across socioeconomic groups in CD diagnoses, with the highest $\mathrm{CD}$ incidence in children from the two least socioeconomically deprived areas, followed by a progressive reduction of $\mathrm{CD}$ incidence in the latter three quintiles (table 1). The lowest incidence was in the most socioeconomically deprived areas. Tables 3 and 4 show, respectively, the absolute rate of $\mathrm{CD}$ and the adjusted IRRs for the association of $\mathrm{CD}$ with socioeconomic status, stratified by sex, age, calendar period and country. We observed a similar relationship between socioeconomic status and CD in both sexes, in all age groups, over time, and in all countries (all LRTs not statistically significant for interaction between these variables and socioeconomic status). There was a statistically significant socioeconomic gradient in each time period other than 1993-1997, when the highest incidence rate was observed in the third quintile. Moreover, although we did not find a statistically significant socioeconomic trend in CD in smaller populations from Wales and Northern Ireland, they also had the highest incidence rate of CD in children from the least socioeconomically deprived areas and the lowest CD incidence rate in children from more socioeconomically deprived areas, in the 5th and 4th quintiles, respectively (figure 1).

\section{Sensitivity analyses}

There were 230 children diagnosed with CD after 2 years of age with a first $C D$ record or gluten-free prescription within 6 months of GP registration (18.4\% potentially prevalent cases out of the total 1247 case population). After excluding these potentially prevalent cases, the overall incidence was 9.7 per 100000 person-years. Variations between subgroups, however, remained similar to the main analyses (see online supplementary table S1). After restricting our CD cases to children with a gluten-free product prescription, there were 1007 children (80.8\% of the total 1247 case population), resulting in an incidence of 9.6 per 100000 person-years. Again, IRRs remained similar to main analyses, showing the same incidence patterns by sex, age, calendar time, country and socioeconomic status (see online supplementary table S2).

\section{DISCUSSION}

\section{Main findings}

The overall CD incidence of 11.9 per 100000 person-years was similar across the UK countries and higher in girls than in boys. While CD incidence up to age 2 remained stable over time, diagnoses in older children have almost tripled over the past 20 years. We found a strong socioeconomic gradient in CD diagnoses such that children living in less socioeconomically deprived areas were about twice as likely to be diagnosed as those in more-deprived areas. This pattern held for boys and girls and for all ages. Across all four countries, we found evidence of a similar socioeconomic gradient in CD diagnosis. 
Table 1 Incidence of coeliac disease ( $\mathrm{N}=2063$ 421)

\begin{tabular}{|c|c|c|c|c|}
\hline & $\begin{array}{l}\text { Number of coeliac } \\
\text { disease cases }\end{array}$ & Person-years & $\begin{array}{l}\text { Rate per } 100000 \\
\text { person-years }(95 \% \mathrm{Cl})\end{array}$ & $\begin{array}{l}\text { Unadjusted incidence } \\
\text { rate ratios }(95 \% \mathrm{CI})\end{array}$ \\
\hline Overall & 1247 & 10508374 & 11.9 (11.2 to 12.5$)$ & \\
\hline \multicolumn{5}{|l|}{ Sex } \\
\hline Male & 514 & 5448627 & 9.4 (8.6 to 10.3$)$ & 1 \\
\hline Female & 733 & 5059747 & 14.5 (13.5 to 15.6$)$ & 1.53 (1.37 to 1.72 ) \\
\hline \multicolumn{5}{|l|}{ Age (years) } \\
\hline$<1$ & 24 & 599728 & $4.0(2.7$ to 6.0$)$ & \\
\hline 1 & 125 & 668994 & 18.7 (15.7 to 22.2 ) & \\
\hline 2 & 119 & 662631 & 17.9 (15.0 to 21.5$)$ & \\
\hline 3 & 91 & 653575 & 13.9 (11.3 to 17.1$)$ & \\
\hline 4 & 97 & 643093 & 15.1 (12.4 to 18.4$)$ & \\
\hline 5 & 67 & 629754 & 10.6 (8.4 to 13.5$)$ & \\
\hline 6 & 81 & 618239 & $13.1(10.5$ to 16.3$)$ & \\
\hline 7 & 74 & 608210 & 12.1 (9.7 to 15.3 ) & \\
\hline 8 & 66 & 597770 & $11.0(8.7$ to 14.0$)$ & \\
\hline 9 & 64 & 587151 & 10.9 (8.5 to 13.9$)$ & \\
\hline 10 & 62 & 576655 & 10.7 (8.4 to 13.8$)$ & \\
\hline 11 & 55 & 566426 & 9.7 (7.4 to 12.6$)$ & \\
\hline 12 & 56 & 554291 & 10.1 (7.7 to 13.1$)$ & \\
\hline 13 & 58 & 539042 & 10.7 (8.3 to 13.9$)$ & \\
\hline 14 & 65 & 521484 & 12.4 (9.7 to 15.9$)$ & \\
\hline 15 & 43 & 507872 & 8.4 (6.3 to 11.4$)$ & \\
\hline 16 & 43 & 495529 & $8.6(6.4$ to 11.7$)$ & \\
\hline 17 & 57 & 477930 & 11.9 (9.2 to 15.5$)$ & \\
\hline \multicolumn{5}{|l|}{ Country } \\
\hline England & 1003 & 8194945 & 12.2 (11.5 to 13.0$)$ & 1 \\
\hline Scotland & 139 & 1286924 & 10.8 (9.1 to 12.7 ) & $0.88(0.73$ to 1.05$)$ \\
\hline Wales & 69 & 649399 & 10.6 (8.4 to 13.4$)$ & 0.87 (0.68 to 1.10$)$ \\
\hline Northern Ireland & 36 & 377106 & 9.5 (6.9 to 13.2$)$ & 0.77 (0.55 to 1.08$)$ \\
\hline \multicolumn{5}{|l|}{ Calendar period } \\
\hline 1993-1997 & 50 & 603213 & 8.3 (6.3 to 10.9$)$ & 1 \\
\hline 1998-2002 & 222 & 2405398 & 9.2 (8 to 1.10 .5$)$ & 1.11 (0.82 to 1.51$)$ \\
\hline 2003-2007 & 404 & 3572886 & $11.3(10.2$ to 12.5$)$ & 1.36 (1.01 to 1.83$)$ \\
\hline 2008-2012 & 571 & 3926877 & 14.5 (13.4 to 15.8$)$ & 1.75 (1.31 to 2.34$)$ \\
\hline \multicolumn{5}{|c|}{ Socioeconomic deprivation (quintile of Townsend index) } \\
\hline 1 (least deprived) & 350 & 2479655 & 14.1 (12.7 to 15.7$)$ & 1.80 (1.45 to 2.22$)$ \\
\hline 2 & 295 & 2032782 & 14.5 (12.9 to 16.2$)$ & 1.85 (1.48 to 2.30$)$ \\
\hline 3 & 221 & 2043017 & 10.8 (9.5 to 12.3$)$ & 1.38 (1.09 to 1.73$)$ \\
\hline 4 & 198 & 1901385 & $10.4(9.0$ to 11.9$)$ & 1.33 (1.05 to 1.67$)$ \\
\hline 5 (most deprived) & 110 & 1402742 & $7.8(6.5$ to 9.4$)$ & 1 \\
\hline Missing & 73 & 648793 & 11.2 (8.9 to 14.1$)$ & 1.43 (1.06 to 1.92$)$ \\
\hline
\end{tabular}

$\mathrm{Cl}$, confidence interval.

\section{Strengths and limitations}

This is the largest study of childhood CD in which the possible role of socio-demographic aspects on the rate of $\mathrm{CD}$ diagnosis has been examined. The demographics of our study population are comparable to those of children in the UK population, ${ }^{27}$ so our findings are likely to be representative of this population. We considered CD diagnosis by using a physician's report as recorded in GP as we did not have comprehensive information on serological or histological testing for each patient. While our pragmatic approach may have resulted in false-positive cases, the accuracy of $\mathrm{CD}$ recording in primary care was specifically validated against medical records ${ }^{28}$ in a small sample of patients, showing a good concordance between paper and electronic records. We used a single diagnostic code to maximise the sensitivity in the main analysis, but when we used a more specific case definition (including only children with at least one CD code and at least one prescription for gluten-free product), the incidence patterns across age, sex, calendar year and socioeconomic status remained very similar to our main analyses. We found that $80.8 \%$ of children with $\mathrm{CD}$ had a prescription for a gluten-free product that was similar to the finding reported by Hall et al. ${ }^{29}$ They conducted a questionnaire study of a sample of patients with CD identified by Read codes in northeast England, and while they confirmed that all patients did have CD disease, only $86.1 \%$ of their patients with CD obtained a gluten-free prescription. We believe therefore that it is unlikely that there has been any great amount of over-ascertainment of CD in our study.

Moving on from our outcome to consider our principal exposure measurement, the Townsend index is a validated measure of how socioeconomically deprived an area is within the UK based on standardised indicators. However, this score 
Table 2 Incidence of coeliac disease over time by sex and age and relative incidence in 2008-2012 compared with 1993-1997 ( $N=2063421$ )

\begin{tabular}{|c|c|c|c|c|c|}
\hline \multicolumn{6}{|l|}{ Calendar period } \\
\hline Calendar year & 1993-1997* & $1998-2002 *$ & $2003-2007^{*}$ & $2008-2012^{*}$ & $\begin{array}{l}\text { Unadjusted IRR for } \\
\text { calendar periodt }(95 \% \mathrm{CI})\end{array}$ \\
\hline \multicolumn{6}{|l|}{ Sex } \\
\hline Male & 7.8 (5.3 to 11.6$)$ & 7.7 (6.3 to 9.3$)$ & 9.3 (7.9 to 10.8$)$ & 10.9 (9.6 to 12.6$)$ & $1.39(0.92$ to 2.10$)$ \\
\hline Female & 8.8 (5.9 to 12.9$)$ & $10.9(9.2$ to 13.0$)$ & 13.5 (11.8 to 15.3$)$ & 18.3 (16.5 to 20.3 ) & 2.09 (1.39 to 3.13$)$ \\
\hline \multicolumn{6}{|l|}{ Age (years) } \\
\hline $0-2$ & 16.7 (11.5 to 24.1$)$ & 14.2 (11.1 to 18.0$)$ & 13.9 (11.3 to 17.3$)$ & $12.9(10.4$ to 15.8$)$ & 0.77 (0.50 to 1.18$)$ \\
\hline $3-9$ & 5.7 (3.4 to 9.7 ) & 8.7 (7.1 to 10.7$)$ & $12.1(10.4$ to 14.0$)$ & 16.4 (14.5 to 18.6$)$ & 2.85 (1.66 to 4.88$)$ \\
\hline 10-18 & 4.1 (2.1 to 8.8$)$ & 7.2 (5.6 to 9.2 ) & 9.4 (7.9 to 11.1$)$ & 13.5 (11.8 to 15.4$)$ & 3.24 (1.60 to 6.56$)$ \\
\hline \multicolumn{6}{|l|}{ Country } \\
\hline England & $8.9(6.7$ to 11.9$)$ & 9.9 (8.6 to 11.4 ) & 11.7 (10.5 to 13.0$)$ & 14.8 (13.5 to 16.2$)$ & 1.65 (1.22 to 2.24$)$ \\
\hline Scotland & - & 5.1 (3.0 to 8.7 ) & 11.2 (8.5 to 14.8 ) & 14.3 (11.3 to 17.9$)$ & $2.77(1.56$ to 4.90$) \ddagger$ \\
\hline Wales & 11.0 (3.5 to 34.2 ) & 9.2 (5.2 to 16.2 ) & 10.3 (6.8 to 15.5$)$ & 11.5 (8.1 to 16.4 ) & 1.04 (0.32 to 3.42$)$ \\
\hline Northern Ireland & $5.9(0.8$ to 42.3$)$ & $6.3(2.8$ to 14.0$)$ & $5.3(2.5$ to 11.2$)$ & 16.4 (10.8 to 24.9$)$ & 2.76 (0.37 to 20.46$)$ \\
\hline
\end{tabular}

Interaction tests: sex and calendar year, LRT $p$ value $=0.4$; age group and calendar year, LRT $p$ value $<0.001$; country and calendar year, LRT $p$ value $=0.05$.

*Incidence rates of coeliac diseases per 100000 person-years $(95 \% \mathrm{CI})$.

tComparing the latest with the earliest calendar period.

¥Since there were no incident coeliac disease cases in the Scottish practices between 1993 and 1997, we used the period 1998-2002 as baseline.

$\mathrm{Cl}$, confidence interval; IRR, incidence rate ratio; LRT, likelihood ratio test.

gives an overall deprivation index of the people living in a particular area of approximately 50 households, not taking into account individual variation in deprivation levels or the differences between urban and rural areas. The small number of CD cases registered in Wales and Northern Ireland reduced the statistical power for these particular analyses.

The relationship between CD diagnosis and socioeconomic grouping did not hold in the time period 1993-1997, which could be related to the differences in diagnosis tools and clinical presentation during that period compared with the following ones. Diagnostic biopsies at that time were frequently carried out by general paediatricians using Crosby or Watson capsules, rather than requiring referral to a paediatric gastroenterologist for endoscopic biopsy. Furthermore, only in the most recent decades has there been a shift towards older average age at diagnosis among children and altered clinical presentation ${ }^{30}$ (ie, less distension, failure to thrive and more subtle symptomatology). ${ }^{31}$ It is possible that these issues could have contributed to the different diagnosis rates among socioeconomic groups that we have observed. An alternative perspective is that the apparently older age at diagnosis observed in various studies has been driven by greater ascertainment and therefore earlier (younger) diagnosis of older ( $>10$ years of age) children. Finally, we cannot exclude that the lack of a gradient seen in the period 1993-1997 was simply related to the lack of adequate sample size during these years.

\section{Comparison with previous literature}

Socioeconomic status has been proposed as a possible factor in the development of $\mathrm{CD}$, although existing studies show

Table 3 Incidence of coeliac disease across socioeconomic groups ( $\mathrm{N}=2063$ 421)

\begin{tabular}{|c|c|c|c|c|c|c|}
\hline Quintile of deprivation & $1=$ least deprived* & $2^{*}$ & $3 *$ & $4^{*}$ & $5=$ most deprived ${ }^{*}$ & Missing \\
\hline \multicolumn{7}{|l|}{ Sex } \\
\hline Male & 11.4 (9.7 to 13.4$)$ & 11.4 (9.5 to 13.6$)$ & 9.3 (7.7 to 11.4$)$ & 7.4 (5.9 to 9.3$)$ & 6.4 (4.8 to 8.5$)$ & 8.2 (5.6 to 11.9$)$ \\
\hline Female & 17.0 (14.8 to 19.6$)$ & 17.9 (15.4 to 20.7$)$ & $12.4(10.4$ to 14.8$)$ & 13.6 (11.4 to 16.2$)$ & $9.4(7.3$ to 12.0$)$ & 14.4 (10.8 to 19.2$)$ \\
\hline \multicolumn{7}{|l|}{ Age (years) } \\
\hline $0-2$ & 15.6 (12.3 to 19.8$)$ & 18.5 (14.5 to 23.5$)$ & 14.4 (11.0 to 18.8$)$ & 10.4 (7.5 to 14.3$)$ & $9.3(6.3$ to 13.8$)$ & 13.1 (8.3 to 20.5 ) \\
\hline $3-9$ & $14.6(12.4$ to 17.1$)$ & 15.7 (13.2 to 18.6$)$ & 9.9 (8.0 to 12.3$)$ & 11.9 (9.7 to 14.6$)$ & $8.3(6.2$ to 11.0$)$ & 11.9 (8.5 to 16.8$)$ \\
\hline $10-18$ & 13.0 (10.9 to 15.4$)$ & 11.6 (9.5 to 14.2$)$ & 10.1 (8.1 to 12.5$)$ & $8.9(7.0$ to 11.3$)$ & 6.7 (4.9 to 9.2 ) & 9.2 (6.0 to 14.2 ) \\
\hline \multicolumn{7}{|l|}{ Calendar period } \\
\hline 1993-1997 & 8.2 (4.5 to 14.9 ) & $5.3(2.4$ to 11.9$)$ & 10.5 (5.9 to 18.5$)$ & 8.1 (4.2 to 15.6$)$ & 4.7 (1.7 to 12.6$)$ & 16.4 (8.2 to 32.8$)$ \\
\hline 1998-2002 & 12.3 (9.7 to 15.6$)$ & $10.0(7.5$ to 13.4$)$ & 8.6 (6.3 to 11.7$)$ & 8.2 (5.9 to 11.5$)$ & 5.2 (3.2 to 8.4$)$ & 8.2 (4.7 to 14.5$)$ \\
\hline $2003-2007$ & $12.6(10.4$ to 15.2$)$ & $14.8(12.2$ to 17.9$)$ & 11.4 (9.1 to 14.2$)$ & 9.3 (7.2 to 12.0$)$ & 7.6 (5.5 to 10.6) & 8.5 (5.4 to 13.5$)$ \\
\hline 2008-2012 & 17.4 (14.9 to 20.4$)$ & 18.4 (15.5 to 21.7$)$ & 11.7 (9.5 to 14.3$)$ & $13.0(10.6$ to 16.0$)$ & $10.2(7.8$ to 13.3$)$ & $14.4(10.3$ to 20.0$)$ \\
\hline \multicolumn{7}{|l|}{ Country } \\
\hline England & $14.2(12.7$ to 15.9$)$ & 14.7 (12.9 to 16.7$)$ & 11.1 (9.6 to 12.8$)$ & $10.9(9.3$ to 12.7$)$ & $8.0(6.4$ to 9.9$)$ & $11.9(9.2$ to 15.4$)$ \\
\hline Scotland & $12.6(8.2$ to 19.1$)$ & 17.0 (12.7 to 22.7$)$ & 9.6 (6.4 to 14.5$)$ & 8.2 (5.4 to 12.6$)$ & 7.1 (4.5 to 11.3$)$ & 9.2 (4.8 to 17.8 ) \\
\hline Wales & $14.4(9.2$ to 22.6$)$ & $10.2(6.0$ to 17.3$)$ & 9.1 (5.3 to 15.6$)$ & 11.4 (6.9 to 18.5$)$ & $7.2(3.2$ to 16.0$)$ & $7.3(1.0$ to 51.9$)$ \\
\hline Northern Ireland & 13.1 (6.2 to 24.2$)$ & 7.8 (3.2 to 18.8$)$ & 11.3 (5.7 to 22.7$)$ & 4.1 (1.0 to 14.4$)$ & 9.1 (4.1 to 20.4) & 9.6 (4.0 to 23.1$)$ \\
\hline
\end{tabular}

*Incidence rates of coeliac diseases per 100000 person-years (95\% Cls).

$\mathrm{Cl}$, confidence interval. 
Table 4 Adjusted incidence rate ratios for the association of coeliac disease with socioeconomic status, stratified by sex, age, calendar period and country ( $\mathrm{N}=2063421)$

\begin{tabular}{|c|c|c|c|c|c|c|c|}
\hline Quintile of deprivation & $1=$ least deprived* & $2 *$ & $3 *$ & $4^{*}$ & $\begin{array}{l}5=\text { most } \\
\text { deprived }\end{array}$ & $\begin{array}{l}p \text { Value } \\
\text { for trend** }\end{array}$ & Missing* \\
\hline \multicolumn{8}{|l|}{ Sex‡ } \\
\hline Male & 1.76 (1.26 to 2.46$)$ & 1.78 (1.26 to 2.50$)$ & 1.45 (1.02 to 2.06$)$ & 1.15 (0.79 to 1.66$)$ & 1 & $<0.001$ & $1.26(0.78$ to 2.03$)$ \\
\hline Female & 1.79 (1.35 to 2.37$)$ & 1.89 (1.42 to 2.52$)$ & 1.30 (0.96 to 1.77$)$ & 1.44 (1.06 to 1.94$)$ & 1 & $<0.001$ & 1.51 (1.03 to 2.20$)$ \\
\hline \multicolumn{8}{|l|}{ Age (years)§ } \\
\hline $0-2$ & 1.57 (0.99 to 2.48$)$ & 1.92 (1.21 to 3.04$)$ & 1.48 (0.92 to 2.38$)$ & 1.08 (0.65 to 1.79$)$ & 1 & 0.004 & $1.38(0.76$ to 2.51$)$ \\
\hline $3-9$ & 1.70 (1.22 to 2.36$)$ & 1.86 (1.33 to 2.59$)$ & 1.17 (0.82 to 1.67$)$ & 1.41 (0.99 to 2.01$)$ & 1 & $<0.001$ & $1.43(0.91$ to 2.23$)$ \\
\hline 10-18 & 1.97 (1.37 to 2.83$)$ & 1.74 (1.19 to 2.53$)$ & 1.52 (1.03 to 2.23$)$ & 1.35 (0.90 to 2.00$)$ & 1 & $<0.001$ & 1.39 (0.82 to 2.37$)$ \\
\hline \multicolumn{8}{|l|}{ Calendar periodt } \\
\hline 1993-1997 & $1.47(0.49$ to 4.63$)$ & $1.00(0.28$ to 3.56$)$ & $1.98(0.63$ to 6.15$)$ & $1.58(0.49$ to 5.14$)$ & 1 & 0.95 & $3.14(0.94$ to 10.50$)$ \\
\hline 1998-2002 & 2.22 (1.31 to 3.79$)$ & 1.87 (1.10 to 3.25$)$ & 1.59 (0.90 to 2.81$)$ & $1.55(0.87$ to 2.76$)$ & 1 & 0.001 & 1.54 (0.73 to 3.24$)$ \\
\hline 2003-2007 & 1.63 (1.11 to 2.38$)$ & 1.92 (1.31 to 2.81$)$ & $1.48(1.00$ to 2.20$)$ & 1.21 (0.81 to 1.83$)$ & 1 & $<0.001$ & 1.11 (0.63 to 1.97$)$ \\
\hline 2008-2012 & 1.71 (1.25 to 2.34$)$ & 1.81 (1.31 to 2.48 ) & $1.15(0.81$ to 1.61$)$ & $1.28(0.92$ to 1.80$)$ & 1 & $<0.001$ & 1.39 (0.91 to 2.13$)$ \\
\hline \multicolumn{8}{|l|}{ Countryף } \\
\hline England & 1.79 (1.04 to 2.30$)$ & 1.86 (1.44 to 2.39$)$ & 1.39 (1.07 to 1.82$)$ & 1.37 (1.04 to 1.79$)$ & 1 & $<0.001$ & 1.47 (1.05 to 2.06$)$ \\
\hline Scotland & $1.66(0.89$ to 3.10$)$ & 2.23 (1.29 to 3.86$)$ & 1.26 (0.68 to 2.34$)$ & 1.11 (0.59 to 2.08$)$ & 1 & 0.004 & $1.21(0.54$ to 2.71$)$ \\
\hline Wales & 2.02 (0.81 to 5.07$)$ & $1.43(0.55$ to 3.73$)$ & $1.26(0.48$ to 3.34$)$ & $1.58(0.62$ to 4.05$)$ & 1 & 0.188 & 0.95 (0.11 to 7.91$)$ \\
\hline Northern Ireland & $1.45(0.53$ to 4.00$)$ & 0.85 (0.26 to 2.80$)$ & 1.20 (0.41 to 3.46$)$ & $0.44(0.08$ to 2.20$)$ & 1 & 0.340 & 1.21 (0.36 to 4.06$)$ \\
\hline \multicolumn{8}{|c|}{$\begin{array}{l}\text { Interaction tests: sex and socioeconomic status, LRT } p \\
\text { countries and socioeconomic status, LRT } p \text { value }=0.87 \text {. } \\
\text { *Incidence rate ratio compared with most deprived (5th } \\
\text { Adjusted for: } ¥ \text { Age and calendar period and country; } \\
\text { §Sex and calendar period and country; } \\
\text { tSex and age and country; } \\
\text { ISex and calendar period and age. } \\
\text { **Excluding missing data. } \\
\text { LRT, likelihood ratio test. }\end{array}$} \\
\hline
\end{tabular}

contradictory results. As table 5 shows, these studies have several differences in study design, outcome, exposure definition, study population and setting. Most of them were conducted using groups of already-diagnosed patients with $\mathrm{CD},{ }^{12-}$ 19 and the only two population-based studies consider patients detected by serological screening rather than clinical diagnosis. $^{20} 21$ Three studies have been conducted in different areas of the UK on children. ${ }^{14} 1518$ Whyte $e t a l^{14}$ reported a higher risk of $\mathrm{CD}$ diagnosis in children, aged $<16$ years, belonging to the least-deprived areas compared with those from the mostdeprived areas in South Wales, which is similar to our results.
This cross-sectional study used The Welsh Index of Multiple Deprivation as a measure of the socioeconomic status that is comparable to the Townsend index. Conversely, a small Scottish cohort study ${ }^{15}$ found no large difference between the Standard Index of Multiple Deprivation and urban/rural indices in children with CD and the general population in Scotland. In 2009, Robert $e a^{18}$ reported that in an area of the South of England children from manual social classes IV and $\mathrm{V}$ had a fourfold increased risk of CD compared with those from professional social classes I and II. Finally, looking at all ages in the UK population, our recent population-based study, using the

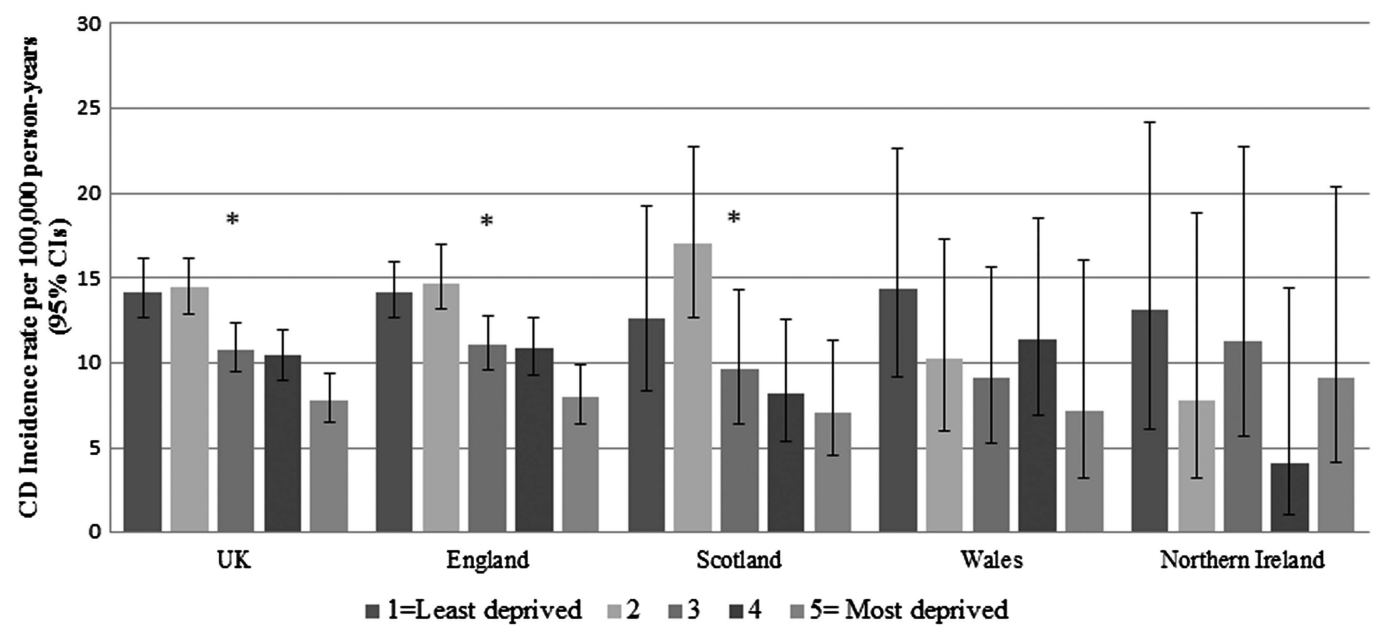

*p-value for trend $<0.05$

Figure 1 Coeliac disease incidence across countries of the UK according to socioeconomic group. $\mathrm{CD}$, coeliac disease; $\mathrm{Cl}$, confidence interval. 


\begin{tabular}{|c|c|c|c|c|c|}
\hline & Geographic area & Study population & $\begin{array}{l}\text { Source of the outcome } \\
\mathrm{N}=\text { number of cases }\end{array}$ & Source of socioeconomic status & Main findings \\
\hline \multicolumn{6}{|c|}{ Diagnosed CD (serology and/or biopsy-positive cases) within medical settings } \\
\hline Burger et $a l^{12}$ & Netherlands & $\begin{array}{l}\text { Subjects identified into the Dutch Pathology } \\
\text { Registry, which covers all pathology labs in } \\
\text { Netherlands } 1995-2010 \\
\mathrm{~N}=6444\end{array}$ & $\begin{array}{l}\mathrm{CD} \text { diagnosis according to biopsy reports } \\
\mathrm{N}=4014\end{array}$ & $\begin{array}{l}\text { The socioeconomic status scores based on income, level } \\
\text { of education and employment }\end{array}$ & $\begin{array}{l}\text { Patients diagnosed with } C D \text { during childhood were } \\
\text { more often from an area with a higher } \\
\text { socioeconomic status compared with patients } \\
\text { diagnosed later in life }(p<0.001)\end{array}$ \\
\hline West et $a l^{13}$ & The UK & $\begin{array}{l}\text { All ages UK population registered with the } \\
\text { Clinical Practice Research Datalink- } \\
\text { 1990-2011 } \\
\text { N=65 } 856848 \text { person-years }\end{array}$ & $\begin{array}{l}\text { People with Read codes representing CD (J690.00; } \\
\mathrm{J} 690.13 ; \mathrm{J} 690 \mathrm{Z} 00 ; \mathrm{J} 690100 ; \mathrm{J} 690.14 ; \mathrm{J} 690000) \\
\mathrm{N}=9087\end{array}$ & Indices of Multiple Deprivation & $\begin{array}{l}\text { The CD incidence was } 27 \% \text { lower in people from the } \\
\text { most-deprived areas than in people from the } \\
\text { least-deprived ones (IRR } 0.83,95 \% \mathrm{Cl} 0.77 \text { to } 0.89 \text { ) }\end{array}$ \\
\hline Whyte et al ${ }^{14}$ & $\begin{array}{l}\text { Cardiff, Newport } \\
\text { and Powys (South } \\
\text { Wales) }\end{array}$ & $\begin{array}{l}\text { The total paediatric population (age }<16 \text { ) in } \\
\text { South Wales (UK national census 2008) } \\
\mathrm{N}=298530 \text { children }\end{array}$ & $\begin{array}{l}\text { CD diagnosis according to ESPGHAN } 1990 \text { criteria in the } \\
\text { same tertiary medical centre between } 1995 \text { and } 2012 \\
N=232\end{array}$ & Welsh Index of Multiple Deprivation & $\begin{array}{l}\text { The prevalence of } C D \text { in the lowest deprivation level } \\
\text { was } 1.16 / 1000 \text { and } 0.49 / 1000 \text { in the highest } \\
\text { deprivation level }\end{array}$ \\
\hline White et $a l^{15}$ & $\begin{array}{l}\text { Southeast } \\
\text { Scotland }\end{array}$ & $\begin{array}{l}\text { The total paediatric population (age }<16) \text { in } \\
\text { Southeast Scotland-1990-2009 (Scotland } \\
\text { census) } \\
N=\sim 225000 \text { children }\end{array}$ & $\begin{array}{l}\text { CD diagnosis according to ESPGHAN } 1990 \text { criteria. Data } \\
\text { from hospital records (ICD codes of CD), paediatric } \\
\text { pathology records, regional clinical database, regional } \\
\text { serology database and the electronic hospital record } \\
\mathrm{N}=266\end{array}$ & $\begin{array}{l}\text { The Scottish government data for the Standard Index of } \\
\text { Multiple Deprivation and urban/rural indices }\end{array}$ & $\begin{array}{l}\text { The median of the Standard Index of Multiple } \\
\text { Deprivation score and urban-rural classification } \\
\text { indices of patients with CD were comparable to the } \\
\text { general population of southeastern Scotland }\end{array}$ \\
\hline Olén et $a l^{16}$ & Sweden & $\begin{array}{l}\text { Individuals aged } 16-64 \text { years using the Total } \\
\text { Population Register } \\
\text { 1969-2008 } \\
N=174186 \text { subjects }\end{array}$ & $\begin{array}{l}\text { CD diagnosis according to biopsy reports collected from } \\
\text { all Swedish pathology departments } \\
\mathrm{N}=29096\end{array}$ & $\begin{array}{l}\text { European Socioeconomic Classification based on } \\
\text { occupation. } \\
\text { Data collected using The Swedish Occupational Register }\end{array}$ & $\begin{array}{l}\text { Individuals from the lowest social class were } 11 \% \\
\text { less likely to be diagnosed with CD (OR } 0.89,95 \% \\
\text { Cl } 0.84 \text { to } 0.94 \text { ) }\end{array}$ \\
\hline $\begin{array}{l}\text { Wingren } \\
\text { et } a l^{17}\end{array}$ & Sweden & $\begin{array}{l}\text { Prospective evaluation of babies born in } \\
\text { Sweden between } 1987 \text { and } 1993 \text { (follow-up } \\
2 \text { years) } \\
N=392568 \text { men and } 372112 \text { women }\end{array}$ & $\begin{array}{l}\text { The Swedish National Hospital Discharge Registry } \\
\text { according to ICD codes of CD } \\
N=845 \text { in men and } 1401 \text { in women }\end{array}$ & $\begin{array}{l}\text { Information on the mothers' pre-tax equalised household } \\
\text { income and social allowance for the year before delivery } \\
\text { (five classes) }\end{array}$ & $\begin{array}{l}\text { Boys born to mothers in an overt low socioeconomic } \\
\text { position had a higher risk of } \mathrm{CD}(\mathrm{OR} 1.37,95 \% \mathrm{Cl} \\
1.03 \text { to } 1.82 \text { ) than those with mothers with high } \\
\text { income and no social allowance }\end{array}$ \\
\hline Robert et al ${ }^{18}$ & $\begin{array}{l}\text { South East } \\
\text { England }\end{array}$ & $\begin{array}{l}\text { Babies born in the south east of England } \\
\text { between } 1970 \text { and } 1999 \text { (mean follow-up } \\
\text { duration } 18 \text { years) using the Oxford record } \\
\text { linkage study database having linked } \\
\text { maternity data in the same dataset } \\
\mathrm{N}=248521\end{array}$ & $\begin{array}{l}\text { Children with both a maternity record and a subsequent } \\
\text { admission for } C D(I C D \text { codes of } C D) \text { in the Oxford record } \\
\text { linkage study database } \\
N=90\end{array}$ & $\begin{array}{l}\text { Information collected from maternal records in the } \\
\text { Oxford record linkage study database }\end{array}$ & $\begin{array}{l}\text { Children from manual social classes IV and V had a } \\
4.02 \text { increased risk of coeliac disease }(95 \% \text { CI1.96 } \\
\text { to } 8.25) \text { compared with those from professional } \\
\text { social classes I and II }\end{array}$ \\
\hline Ludvigsson $^{19}$ & Sweden & $\begin{array}{l}\text { Babies born in southeast Sweden between } \\
1997 \text { and } 1999 \text { (follow-up } 15 \text { years) } \\
N=15875 \text { single births }\end{array}$ & $\begin{array}{l}\text { Coeliac cases reported by eight paediatric departments } \\
\text { A case was included if he had intestinal biopsy } \\
\text { suggesting } C D \text {, no symptoms after the introduction of a } \\
\text { gluten-free diet and/or no or only minor } \\
\text { histopathological abnormalities consistent with CD at } \\
\text { the control biopsy under treatment with gluten-free diet } \\
\mathrm{N}=45\end{array}$ & $\begin{array}{l}\text { Information collected in questionnaire completed by the } \\
\text { mothers shortly after childbirth on: place of living } 1 \text { year } \\
\text { before conception, maternal employed during pregnancy, } \\
\text { paternal employed the year before the conception, family } \\
\text { crowed living }\end{array}$ & $\begin{array}{l}C D \text { was less common in mothers who had worked } \\
<3 \text { months during pregnancy }(\mathrm{OR}=0.29 ; 95 \% \mathrm{Cl} \\
0.09 \text { to } 0.94 ; \mathrm{p}=0.039) \text {. The other socioeconomic } \\
\text { factors were not associated }\end{array}$ \\
\hline \multicolumn{6}{|c|}{ Screening detected $C D$ in the general population } \\
\hline $\begin{array}{l}\text { Kondrashova } \\
\text { et } a^{20}\end{array}$ & $\begin{array}{l}\text { Finland and } \\
\text { Russia }\end{array}$ & $\begin{array}{l}\text { Schoolchildren } \\
\text { Russia Karelia: age ranged } 6.2-18.3 \text { years } \\
\text { (1997-2001) } \\
\mathrm{N}=1988 \text { children } \\
\text { Northern Finland: age ranged } 7-18 \text { years } \\
\text { (1994) } \\
\mathrm{N}=3654 \text { children }\end{array}$ & $\begin{array}{l}\text { Serological screening by tTGA } \\
\text { All subjects who were positive were offered an intestinal } \\
\text { biopsy to confirm CD diagnosis. } \\
\mathrm{N}=4 \text { in Russia and } 34 \text { in Finland }\end{array}$ & $\begin{array}{l}\text { Comparison between two areas with opposite } \\
\text { socioeconomic condition (poor Russia vs rich Finland). }\end{array}$ & $\begin{array}{l}0.6 \% \text { of the children }(12 / 1988 ; \mathrm{Cl} 0.3 \% \text { to } 1.1 \%) \text { in } \\
\text { Russian Karelia tested positive for tTGA compared } \\
\text { with } 1.4 \%(52 / 3654 ; \mathrm{Cl} 1.1 \% \text { to } 1.9 \%) \text { in the } \\
\text { Finnish cohort. Biopsy-proven } \mathrm{CD}: \mathrm{N}=4 \text { in Russia and } \\
34 \text { in Finland (no biopsy in } 13 \text { subjects) }\end{array}$ \\
\hline West et $a l^{21}$ & Cambridge & $\begin{array}{l}\text { Participants, age } 45-76 \text { years registered with } \\
\text { a general practice in Cambridge, England } \\
\text { (1990-1995) } \\
N=7527\end{array}$ & $\begin{array}{l}\text { Serological screening by EMA } \\
\mathrm{N}=87\end{array}$ & $\begin{array}{l}\text { Participant-reported occupation categorised as } \\
\text { professional, skilled, unskilled/partly skilled }\end{array}$ & $\begin{array}{l}\text { EMA positivity less common in partly skilled or } \\
\text { unskilled workers, as compared to professionals } \\
\text { (OR } 0.51,95 \% \text { CI } 0.18 \text { to } 1.43 \text { ) }\end{array}$ \\
\hline
\end{tabular}


Clinical Practice Research Database, ${ }^{13}$ also described that CD occurred more commonly in areas with the least socioeconomic deprivation. Outside the UK, three Swedish studies ${ }^{16} 1719$ have reported contradictory results on the association between socioeconomic status and CD (table 5). Similarly to our results, Burger et $a l^{12}$ have recently described, using registered pathology reports in the Netherlands, that patients diagnosed in childhood were more often from higher socioeconomic status compared with patients diagnosed later in life.

\section{Interpretation}

It is not possible from this study nor from previous literature to conclusively explain the reasons for this gradient, which may indicate either that the ascertainment of disease varies among social classes or that there is a true variation in incidence by socioeconomic status. For example, individuals from moredeprived areas may be less likely to seek medical care or consultation in general and thus be potentially less likely to be tested for CD. ${ }^{10} 3233$ Aside from ascertainment, however, it is also possible that people of different socioeconomic groups are exposed to different risk factors, which might indirectly contribute to CD development. Two studies of screening-detected CD (table 5), one in the UK showing a weak socioeconomic gradi$\mathrm{ent}^{21}$ and the other reporting a higher prevalence of detected $\mathrm{CD}$ in children from Finland than in those from a more socioeconomically deprived Russian area, ${ }^{20}$ may support this conjecture. The duration of exclusive breast feeding and the optimal timing of gluten introduction for infants in terms of their contribution to the risk of developing $\mathrm{CD}$ have been debated for several years. Previous studies have implied a window of time (4-6 months of age) during which the introduction of gluten might facilitate induction of tolerance (window of tolerance) $;^{34-38}$ however, evidence from two newly published clinical trials has not confirmed this. ${ }^{39} 40$ Vriezinga et al recruited HLA-DQ2 or HLADQ8-positive newborns with a first-degree relative affected by CD from eight countries and showed no difference in the risk of CD by 3 years of age between infants randomised to $100 \mathrm{mg}$ of immunologically active gluten daily (combined with lactose) and those given a placebo (lactose only) between 4 and 6 months. ${ }^{39}$ Furthermore, they observed no association of breastfeeding duration, regardless of whether it was exclusive or with gluten introduction, with $\mathrm{CD}$ development. Lionetti et $a l^{40}$ conducted a trial in Italy of predisposed newborns (those with a first-degree relative with CD) and found that the introduction of gluten at 12 months vs 6 months slightly delayed the onset of CD, but CD prevalence was no different by 5 years of age. In addition, the authors did not detect any effect of breast feeding on the development of CD. These trials do not support the possibility that differences in time of gluten introduction or breastfeeding duration explain the socioeconomic gradient we observed in our population. Furthermore, an analysis of breast feeding in England showed a lower prevalence of exclusive breast feeding at 6-8 weeks postdelivery among women from the most-deprived areas than in the leastdeprived areas. ${ }^{41}$ Since the higher incidence of CD in children from less-deprived groups that we observed is opposite to the relationship this would be expected to cause, this is further evidence that known differences in breast feeding are unlikely to explain the socioeconomic gradient of CD.

Another potential explanation of the observed socioeconomic gradient could be related to the so-called hygiene hypothesis. ${ }^{42}$ This hypothesises that a decreased antigenic exposure in childhood in less-deprived groups causes an immunological overreaction at the time of a subsequent antigenic contact, ${ }^{42} 43$ that is, gluten in the case of CD. A greater exposure to childhood infection may also occur in children of lower socioeconomic groups, ${ }^{44}$ which could eventually protect them from later development of CD via this mechanism. This explanation, however, is inconsistent with previous evidence of early infections as a potential risk factor for CD. ${ }^{45}{ }^{46}$ Lastly, little is known about dietary variation in gluten according to socioeconomic group, ${ }^{47}$ so we cannot speculate whether this may play a role. ${ }^{48}$

\section{CONCLUSION}

Based on the current evidence, the most plausible explanation for the socioeconomic gradient in the incidence of childhood CD whereby children from least-deprived areas have CD diagnosed more often than those from the most-deprived areas is that ascertainment of disease varies rather than the true occurrence of CD. Awareness campaigns and the implementation of diagnostic guidelines may help to implement strategies for casefinding in all children and reduce this inequality. Moreover, a greater use of the new paediatric guidelines ${ }^{49} 50$ with the possibility to diagnose symptomatic cases without biopsy might increase the access to diagnosis in children from the mostdeprived areas. Future studies might continue to explore the possible association between exposures to different specific risk factors with the occurrence of CD across socioeconomic groups.

Contributors FZ conceptualised and designed the study, drafted the initial manuscript, carried out the statistical analysis and approved the final manuscript as submitted. JW conceptualised and designed the study, obtained the funding, coordinated and supervised data analysis, reviewed and revised the manuscript, and approved the final manuscript as submitted. CJC, KMF and TRC reviewed and revised the manuscript, obtained the funding, and approved the final manuscript as submitted. CC reviewed and revised the manuscript and approved the final manuscript as submitted. LJT conceptualised and designed the study, obtained the funding, prepared the data and initial analysis, coordinated and supervised data analysis, critically reviewed the manuscript and approved the final manuscript as submitted.

Funding Supported by CORE/Coeliac UK; JW is funded by a University of Nottingham/Nottingham University Hospitals NHS Trust Clinical Senior Research Fellowship, which also partly funds FZ's PhD.

\section{Competing interests None.}

Ethics approval THIN Scientific Review Committee (protocol 13-075).

Provenance and peer review Not commissioned; externally peer reviewed.

Open Access This is an Open Access article distributed in accordance with the Creative Commons Attribution Non Commercial (CC BY-NC 4.0) license, which permits others to distribute, remix, adapt, build upon this work non-commercially, and license their derivative works on different terms, provided the original work is properly cited and the use is non-commercial. See: http://creativecommons.org/ licenses/by-nc/4.0/

\section{REFERENCES}

1 Fasano A, Berti I, Gerarduzzi T, et al. Prevalence of celiac disease in at-risk and not-at-risk groups in the United States: a large multicenter study. Arch Intern Med 2003; $163: 286$.

2 Tommasini A, Not T, Kiren $\mathrm{V}$, et al. Mass screening for coeliac disease using antihuman transglutaminase antibody assay. Arch Dis Child 2004;89:512-15.

3 Mäki M, Mustalahti K, Kokkonen J, et al. Prevalence of celiac disease among children in Finland. N Engl J Med 2003;348:2517-24.

4 Mustalahti K, Catassi C, Reunanen A, et al. The prevalence of celiac disease in Europe: results of a centralized, international mass screening project. Ann Med 2010;42:587-95.

5 Rubio-Tapia A, Ludvigsson JF, Brantner TL, et al. The prevalence of celiac disease in the United States. Am J gastroenterol 2012;107:1538-44.

6 Bingley PJ, Norcross AJ, Lock RJ, et al. Undiagnosed coeliac disease at age seven: population based prospective birth cohort study. BMJ 2004;328:322-3.

7 Kang JY, Kang $A H$, Green A, et al. Systematic review: worldwide variation in the frequency of coeliac disease and changes over time. Aliment Pharmacol Ther 2013:38:226-45.

8 Rostom A, Dubé C, Cranney A, et al. The diagnostic accuracy of serologic tests for celiac disease: a systematic review. Gastroenterology 2005;128:S38-46. 
9 Aggarwal S, Lebwohl B, Green PH. Screening for celiac disease in average-risk and high-risk populations. Therap Adv Gastroenterol 2012;5:37-47.

10 Goddard M, Smith P. Equity of access to health care services: Theory and evidence from the UK. Soc Sci Med 2001:53:1149-62.

11 Costa Font J, Hernández-Quevedo C, McGuire A. Persistence despite action? Measuring the patterns of health inequality in England (1997-2007). Health Policy 2011;103:149-59.

12 Burger JP, Roovers EA, Drenth JP, et al. Rising incidence of celiac disease in the Netherlands; an analysis of temporal trends from 1995 to 2010. Scand J Gastroenterol 2014:1-9.

13 West J, Fleming KM, Tata $L$, et al. Incidence and prevalence of celiac disease and dermatitis herpetiformis in the UK over two decades: population-based study. Am J Gastroenterol 2014;109:757-68.

14 Whyte L, Kotecha S, Watkins W, et al. Coeliac disease is more common in children with high socio-economic status. Acta Paediatr 2014;103:289-94.

15 White LE, Merrick VM, Bannerman E, et al. The rising incidence of celiac disease in Scotland. Pediatrics 2013;132:e924-31.

16 Olén $\mathrm{O}$, Bihagen $\mathrm{E}$, Rasmussen $\mathrm{F}$, et al. Socioeconomic position and education in patients with coeliac disease. Dig Liver Dis 2012:44:471-6.

17 Wingren CJ, Björck S, Lynch KF, et al. Coeliac disease in children: a social epidemiological study in Sweden. Acta Paediatr 2012;101:185-91.

18 Roberts S, Williams J, Meddings D, et al. Perinatal risk factors and coeliac disease in children and young adults: a record linkage study. Aliment Pharmacol Ther 2009;29:222-31.

19 Ludvigsson J. Socio-economic characteristics in children with coeliac disease. Acta Paediatr 2005:94:107-13.

20 Kondrashova A, Mustalahti K, Kaukinen K, et al. Lower economic status and inferior hygienic environment may protect against celiac disease. Ann Med 2008:40:223-31

21 West J, Logan R, Hill P, et al. Seroprevalence, correlates, and characteristics of undetected coeliac disease in England. Gut 2003;52:960-5.

22 Lewis JD, Schinnar R, Bilker WB, et al. Validation studies of the health improvement network (THIN) database for pharmacoepidemiology research. Pharmacoepidemiol Drug Saf 2007;16:393-401.

23 Townsend P. Deprivation. J Soc Policy 1987;16:125-46.

24 Wingren CJ, Agardh D, Merlo J. Sex differences in coeliac disease risk: a Swedish sibling design study. Dig Liver Dis 2012;44:909-13.

25 McGowan KE, Castiglione DA, Butzner JD. The changing face of childhood celiac disease in North America: impact of serological testing. Pediatrics 2009;124:1572-8.

26 Lewis JD, Bilker WB, Weinstein RB, et al. The relationship between time since registration and measured incidence rates in the General Practice Research Database. Pharmacoepidemiol Drug Saf 2005;14:443-51.

27 NHS. Information Centre: Final General Practice Registered Populations. 2011. http://www.ic.nhs.uk/statistics-and-data-collections/population-and-geography/ gp-registered-populations/attribution-dataset-gp-registered-populationsscaled-to-onspopulation-estimates-2011

28 West J. Studies of its frequency and consequence, in Division of Epidemiology and Public Health 2005, University of Nottingham.

29 Hall NJ, Rubin GP, Charnock A. Intentional and inadvertent non-adherence in adult coeliac disease. A cross-sectional survey. Appetite 2013;68:56-62.
30 Kelly D, Phillips A, Elliott E, et al. Rise and fall of coeliac disease 1960-85. Arch Dis Child 1989;64:1157-60.

31 Steens RF, Csizmadia CG, George EK, et al. A national prospective study on childhood celiac disease in the Netherlands 1993-2000: an increasing recognition and a changing clinical picture. J Pediatr 2005;147:239-43.

32 Kozyrskyj AL, Dahl ME, Chateau DG, et al. Evidence-based prescribing of antibiotics for children: role of socioeconomic status and physician characteristics. Can Med Assoc J 2004:171:139-45.

33 Braveman P. Health disparities and health equity: concepts and measurement. Annu Rev Public Health 2006;27:167-94.

34 Ivarsson A, Persson L, Nyström L, et al. Epidemic of coeliac disease in Swedish children. Acta Paediatr 2000;89:165-71.

35 Ivarsson A, Myléus A, Norström F, et al. Prevalence of childhood celiac disease and changes in infant feeding. Pediatrics 2013;131:e687-94.

36 Ivarsson $\mathrm{A}$, Hernell $\mathrm{O}$, Stenlund $\mathrm{H}$, et al. Breast-feeding protects against celiac disease. Am J Clin Nutr 2002;75:914-21.

37 Norris JM, Barriga K, Hoffenberg EJ, et al. Risk of celiac disease autoimmunity and timing of gluten introduction in the diet of infants at increased risk of disease. JAMA 2005:293:2343-51.

38 Størdal K, White RA, Eggesbø M. Early feeding and risk of celiac disease in a prospective birth cohort. Pediatrics 2013;132:e1202-9.

39 Vriezinga SL, Auricchio R, Bravi E, et al. Randomized feeding intervention in infants at high risk for celiac disease. N Eng/ J Med 2014;371:1304-15.

40 Lionetti E, Castellaneta S, Francavilla R, et al. Introduction of gluten, HLA status, and the risk of celiac disease in children. N Eng/ J Med 2014;371:1295-303.

41 Oakley LL, Renfrew MJ, Kurinczuk JJ, et al. Factors associated with breastfeeding in England: an analysis by primary care trust. BMJ Open 2013;3:pii: e002765.

42 Brown EM, Arrieta M-C, Finlay BB. A fresh look at the hygiene hypothesis: How intestinal microbial exposure drives immune effector responses in atopic disease. Semin Immunol 2013;25:378-87.

43 Rautava S, Isolauri E. The development of gut immune responses and gut microbiota: effects of probiotics in prevention and treatment of allergic disease. Curr Issues Intestinal Microbiol 2002;3:15-22.

44 Simonsen J, Frisch M, Ethelberg S. Socioeconomic risk factors for bacterial gastrointestinal infections. Epidemiology 2008;19:282-90.

45 Welander A, Tjernberg AR, Montgomery SM, et al. Infectious disease and risk of later celiac disease in childhood. Pediatrics 2010;125:e530-6.

46 Myléus $A$, Hernell 0 , Gothefors $L$, et al. Early infections are associated with increased risk for celiac disease: an incident case-referent study. BMC Pediatr 2012;12:194.

47 Nelson M, Dick K, Holmes B. Food budget standards and dietary adequacy in lowincome families. Proc Nutr Soc 2002;61:569-77.

48 Kasarda DD. Can an increase in celiac disease be attributed to an increase in the gluten content of wheat as a consequence of wheat breeding? J Agric Food Chem 2013:61:1155-9.

49 Husby S, Koletzko S, Korponay-Szabo I, et al. European Society for Pediatric Gastroenterology, Hepatology, and Nutrition guidelines for the diagnosis of coeliac disease. J Pediatr Gastroenterol Nutr 2012;54:136-60.

50 Murch S, Jenkins H, Auth M, et al. Joint BSPGHAN and Coeliac UK guidelines for the diagnosis and management of coeliac disease in children. Arch Dis Child 2013:98:806-11. 